\title{
PROGRAM HOMESTAY UNTUK PENGEMBANGAN EKONOMI MASYARAKAT DI KAMPUNG KREATIF CIBUNUT
}

\author{
Mutia Tri Satya \\ mutia.satya@gmail.com \\ Ayi Tejaningrum \\ tejaningrumayi@gmail.com \\ Hanifah \\ hanifahoney@gmail.com
}

SEKOLAH TINGGI ILMU EKONOMI EKUITAS

\begin{abstract}
ABSTRAK
Cibunut melakukan inovasi yaitu dengan menjadikan salah satu kawasannya menjadi tempat wisata. Melihat banyaknya wisatawan yang berkunjung, ketua $R W$ berinisiatif membangun program homestay agar para wisatawan yang datang tidak hanya berkunjung tetapi akan mengahabiskan waktu beberapa hari untuk menikmati kampung kreatif Cibunut, yang otomatis akan semakin meningkatkan perekonomian masyarakat Cibunut. Maka dari itu, program homestay dilakukan untuk mengembangkan dan meningkatkan perekonomian masyarakat dengan cara memberikan pelatihan secara tatap muka mengenai pengelolaan homestay serta Website sebagai sarana pemasaran. Pemberian banner yang menggambarkan profil Cibunut juga dilakukan untuk menambah media promosi kampung Cibunut. Hasil program ini menunjukkan bahwa adanya peningkatan pemahaman warga Cibunut mengenai pengolahan homestay yang terstandarisasi, mengelola Website sebagai media pemasaran serta menciptakan lingkungan yang lebih bersih.
\end{abstract}

Kata kunci: Kampung Kreatif, Homestay, Web.

\section{PENDAHULUAN}

Perkembangan pariwisata di Kota Bandung semakin pesat, namun masih berpusat di area pekotaan dengan kegiatan aktivitas belanja di area factory outlet maupun distro yang tersebar di wilayah tersebut, atau di area bandung utara yang memang identik dengan pusat wisata alam di kota Bandung. Hal tersebut menyebabkan perkembangan pariwisata lebih banyak dinikmati oleh investor dengan kemampuan financial yang tinggi. Ini menjadikan timbulnya wilayah lain di Kota Bandung yang mengalami ketertinggalan dari segi ekonomi karena tidak mendapatkan manfaat dari perkembangan pariwisata. Menyikapi hal tersebut, beberapa masyarakat bersama para relawan dengan giat membangun kembali wilayahnya dan membentuk sebuah Kampung Kreatif agar mampu mensejahterakan dengan memanfaatkan perkembangan pariwisata. Salah satunya adalah Kampung Kreatif Cibunut.

Kampung Kreatif Cibunut berlokasi di jalan sunda di kota Bandung, penggagasan Cibunut menjadi Kampung Kreatif dilakukan oleh masyarakatnya sendiri. 
Dalam dua tahun pertama penggagasan kampung kreatif, kestabilan lingkungan Kampung Cibunut ini sudah terlihat, padahal sebelumnya Cibunut merupakan daerah rawan, terdapat banyak copet serta pengguna narkoba, namun hal tersebut mampu diatasi setelah Cibunut menjadi Kampung Kreatif. Pendirian kampung ini melibatkan komunitas-komunitas dari berbagai kelompok umur mulai dari TK, Pemuda (SMP, SMA, dan sederajat), hingga kalangan orang tua berpartisipasi dalam pengembangan Kampung Wisata Kreatif

Hal yang menjadi keunggulan kampung Cibunut ini adalah mural tematiknya yang terdapat di setiap RT. Bahkan, dengan adanya pengaruh media sosial Kampung Cibunut mendapatkan kunjungan dari Ketua mural sedunia. Kampung Kreatif Cibunut juga menjadi Kampung Percontohan di Indonesia untuk kampung daur ulang sampah. Dimana, semua sampah yang ada di Kampung Cibunut ini tidak ada yang terbuang begitu saja namun dimanfaatkan kembali melalui proses daur ulang.

Secara Ekonomi, Kampung Kreatif Cibunut ini mendapat keuntungan dari pengolahan limbah sampah serta aktivitas wisata yang terdapat di dalamnya sudah sangat di minati wisatawan, membuat ekonomi masyarakatnya meningkat. Hal tersebut menunjukan bahwa gagasan kampung kreatif cepat berkembang. Ketika suatu kegiatan dibentuk oleh masyarakat akan terlihat berbeda dengan kegiatan yang dibentuk oleh pemerintah, kegiatan yang dibentuk masyarakat akan terlihat jauh lebih keren bahkan melebihi ekspektasi karena masyarakat melakukan kegiatan tersebut dengan bahu membahu

Melihat banyaknya wisatawan yang datang maka tokoh yang ada di Cibunut merencanakan program untuk membangun homestay. Usaha homestay atau pondok wisata dipahami sebagai penyedia akomodasi berupa bangunan rumah tinggal yang dihuni oleh pemiliknya dan dimanfaatkan sebagian untuk disewakan dengan memberikan kesempatan kepada wisatawan untuk berinteraksi dalam kehidupan sehari - hari pemiliknya. (Permen Pariwisata dan Ekonomi Kreatifi RI Nomor 9 Tahun 2014), dimana nantinya para wisatawan datang tidak hanya untuk berkunjung tetapi juga akan menghabiskan beberapa hari untuk menikmati kreatifitas yang ada di Cibunut yang merupakan inovasi dari masyarakatnya sendiri

Selain itu juga kami melakukan pelatihan mengenai Web (World Wibe Web) yaitu salah satu layanan yang didapat oleh pemakai computer yang menghubung ke internet. Yang nantinya akan membantu untuk memperkenalkan tentang kampung kreatif Cibunut secara lebih luas lagi.

Wilayah RT 05 yang dipilih untuk dibuatnya program homestay karena di kawasan tersebut merupakan kawasan aktivitas pusat pengolahan sampah, warga setempat menyebutnya area lapang. Namun dari banyak keunggulan yang dimiliki Cibunut, masyarakatnya tidak atau belum mengetahui cara yang tepat dan bagaimana program homestay ini berjalan.

Maka dari itu kami tim dosen STIE melakukan program pelatihan homestay dan pengenalan Web untuk pengembangan ekonomi wilayah Cibunut. Kami akan memberikan pemahaman mengenai cara membentuk dan mengembangkan homestay dan memberikan fasilitas pelatihan untuk membuat serta mengelola Website atau Web yang sangat penting untuk mendukung kemajuan pariwisata di Cibunut. Dengan semakin majunya jaman maka banyak hal yang dapat di manfaat kan salah satunya melalui social media. seperti yang dikatakan oleh Yuhefizar. Menurut pendapat dari Yuhefizar, "Website merupakan suatu metode untuk menampilan informasi di internet, baik berupa teks, gambar, suaramaupun video yang interaktif dan mempunyai kelebihan untuk menghubungkan (link) satu dokumen dengan dokumen lainnya (hypertext) yang dapat diakses melalui sebuah browse."

Nantinya masyarakat sekitar diharapkan mampu mengelola sumber daya yang ada dan mampu mempertahankan serta mengembangkan pariwisata yang ada 
melalui berbagai cara. Salah satunya melalui program homestay ini. Melalui pelatihan ini juga diharapkan dapat membuat masyarakat mengetahui standar rumah yang dapat di jadikan untuk homestay. Kami juga akan melakukan binaan untuk mengelola manajemen yang baik agar masyarakat mampu mengatur keberlansungan program ini. karena untuk mengelola ini semua di perlukan pemahaman tentang manajemen usaha.

\section{METODE PELAKSANAAN}

Metode pelatihan ini diberikan dengan cara tatap muka dan pelatihan langsung kepada peserta. Untuk melakukan pelatihan ini ada beberapa hal yang dilakukan oleh tim dosen :

1. Melakukan pelatihan program homestay membahas mengenai bagaimana cara membentuk dan mengembangkan homestay yang tidak hanya layak untuk ditempati namun juga memiliki konsep dan tema yang menarik agar mampu menarik kunjungan para wisatawan.

2. Dari sisi manajemen
* Pelatihan Web untuk mendukung strategi pemasaran kampung kreatif secara online (melalui social media) maupun offline.
* Memotivasi untuk berwirausaha, membangkitkan motivasi untuk terus menciptakan karya - karya dan menghasilkan sesuatu yang bernilai yang nantinya akan ikut juga berperan dalam mempertahankan pariwisata Cibunut.

Beberapa tahapan yang dilakukan dalam program ini dijabarkan sebagai berikut:

1. Tahap awal dilakukan dengan mengidentifikasi lingkungan RT 05 Kampung Kreatif Cibunut. Setelah dilakukan investigasi, selanjutnya dilakukan pemilihan serta pengelompokkan warga RT 05 Kampung Kreatif Cibunut sebagai target yang akan menerima program pelatihan. Pelaksanaan program pelatihan, dihadiri oleh 15 orang peserta.

2. Tahap lanjutan, dilakukan dengan mensosialisasikan program Homestay yang sudah direncanakan dengan tokoh setempat kepada warga RT 05 Kampung Kreatif Cibunut. Selain itu, dilakukan juga penyediaan banner yang menggambarkan profil kampung cibunut, agar membantu pengunjung memperoleh informasi serta gambaran mengenai kampung ini. Target dari tahap ini adalah, para peserta mampu memahami bagaimana cara mengelola dan membentuk standar yang tepat untuk homestay serta mampu menggunakan media sosial salah satunya melalui Website sebagai salah satu media pemasaran dan informasi untuk mengenalkan Kampung Kreatif Cibunut kepada wisatawan di luar kota Bandung.

3. Tahap akhir, dilakukan dengan melakukan monitoring dan pendampingan pasca dilaksanakannya program untuk melihat hasil dan perkembangan setelah diadakannya program pelatihan homestay Kampung Kreatif Cibunut hingga terciptanya kemandirian pelaku usaha.

\section{HASIL DAN LUARAN}

Program Pelatihan ini telah dilaksanakan secara langsung dengan jumlah peserta yang hadir sebanyak 15 orang yang merupakan warga dari Rt. 05 Kampung Kreatif Cibunut. Hasil dan luaran pengabdian kepada masyarakat ini, berupa pamaham mengenai program homestay dan bagaimana mengelola pariwisata yang ada di kampung kreatif Cibunut. Berikut hasil dan luaran untuk masyarakat Cibunut: 
1. Terciptanya pemahaman mengenai bagaimana mengelola program homestay yang baik dengan melakukan standarisasi mengenai kelayakan tempat untuk dijadikan homestay. Hal tersebut terlihat dari gagasan dari salah satu peserta yang bersedia agar rumahnya dijadikan sebagai salah satu contoh homestay di wilayah tersebut.

2. Menjaga lingkungan tetap bersih yaitu dengan melakukan daur ulang terhadap sampah-sampah yang ada dilokasi Cibunut dan menjadikannya sebagai karya yang memiliki nilai tambah. Terlihat dari lingkungan yang terawat, serta adanya pondok atau pos khusus untuk pengelolaan sampah

3. Pemahaman engenai Web untuk mengelola bagaimana proses pemasaran yang baik dan juga kegiatan lainnya seperti mengelola keuangan (accounting) yang nantinya akan memudahkan masyarakat untuk melakukan kegiatan dalam upaya mempertahakan Kampung Kreatif. Peserta mampu membuat dan mengelola Website sendiri.

\section{KESIMPULAN}

Program homestay sangat efektif untuk mempertahankan dan menarik kunjungan wisatawan yang nantinya tidak hanya untuk berkunjung tetapi juga untuk menikmati kampung kreatif selama beberapa hari. Ini juga akan memajukan perekonomian di masyarakat sekitar.

\section{DAFTAR PUSTAKA}

Madani, Moch A. 2017). Mengintip Kampung Kreatif Cibunut di Bandung. https://republika.co.id/berita/inpicture /nasionalinpicture/p02wy0283/mengintipkampung-kreatif-cibunut-di-bandung4. (Diakses pada tanggal 23 September 2019)
Republik Indonesia, Peraturan Menteri Pariwisata dan Ekonomi Kreatif Nomor 9/2014 tentang Standar Usaha Pondok Wisata. 